PONTIFÍCIA UNIVERSIDADE CATÓLICA DO RIO DE JANEIRO

\title{
Análise e Comparação da Percepção, Atitude e Motivação de Consumidores Leais e Tradicionais de Casa \& Conforto
} Virginia Estabile de Araujo Pinho

Trabalho de Conclusão de Curso

Centro de CIÊnCIAS SOCIAIS - CCS

DEPARTAMENTO DE ADMINISTRAÇÃO

Graduação em Administração de Empresas 
Virginia Estabile de Araujo Pinho

\author{
Análise e Comparação da Percepção, Atitude e Motivação \\ de Consumidores Leais e Tradicionais de Casa \& Conforto
}

Trabalho de Conclusão de Curso

Trabalho de Conclusão de Curso, apresentado ao programa de graduação em Administração da PUC-Rio como requisito parcial para a obtenção do titulo de graduação em Administração.

Orientador: Marcus Wilcox Hemais

Rio de Janeiro, novembro de 2021. 


\section{Agradecimentos}

Agradeço primeiramente à minha família por todo apoio, carinho e confiança durante todos os momentos da minha vida. Também gostaria de agradecer por todo esforço investido para me oferecer as melhores oportunidades no âmbito acadêmico e pessoal. Obrigada por sempre estarem ao meu lado e serem minha base. Igualmente, agradeço ao Gabriel de Souza por todo incentivo, suporte e atenção na reta final dessa etapa.

Também gostaria de agradecer aos meus amigos, principalmente os da faculdade, que tornaram a rotina muito mais leve e divertida. Vocês foram fundamentais na minha experiencia como universitária.

Agradeço aos incríveis professores de Administração de Empresas da PUC-Rio. Em especial, ao meu orientador Marcus Hemais que foi essencial na conclusão do meu ensino superior.

Aos Louquitos e outros consumidores que aceitaram participar da entrevista e me ajudaram a realizar minha pesquisa.

Por fim, gostaria de agradecer ao meu time de marcas próprias, principalmente Laura Machado, Patrícia Gralheiro, Ana Beatriz Fernandes, Rafaela dos Santos e Nicole Madesn, que me acolheu e me ensinou muito durante esse período de estágio. 


\section{Resumo}

Araujo Pinho, Virginia Estabile de. Análise e Comparação da Percepção, Atitude e Motivação de Consumidores Leais e Tradicionais de Casa \& Conforto. Rio de Janeiro, 2021. 49 p. Trabalho de Conclusão de Curso Departamento de Administração. Pontifícia Universidade Católica do Rio de Janeiro.

O presente estudo teve como objetivo analisar e comparar a percepção, a motivação e a atitude de consumidores leais e consumidores tradicionais da marca própria Casa \& Conforto do Shoptime. Para isso, foram realizadas entrevistas em profundidade com dois tipos de consumidores, os leais e os tradicionais. Os consumidores leais são se intitularam de Louquitos visto que são membros de um grupo nas redes sociais chamados de "Loucos por Shoptime" que foi criado com o objetivo de compartilhar dicas de compras e promoções. Os consumidores tradicionais são considerados os outros clientes da marca. As entrevistas possibilitaram a comparação das diferenças e semelhanças entre a percepção, a atitude e motivação desses consumidores.

Palavras- chave: Percepção, Atitude, Motivação, Lealdade, Casa \& Conforto, Shoptime. 


\begin{abstract}
Araujo Pinho, Virginia Estabile de. The analysis and comparison of the perception, attitude, and motivation of Casa \& Conforto's loyal and traditional consumers. Rio de Janeiro, ano. 49 p. Trabalho de Conclusão de Curso - Departamento de Administração. Pontifícia Universidade Católica do Rio de Janeiro.
\end{abstract}

This work aims to analyse and compare the perception, attitude, and motivation of Casa \& Conforto's loyal and traditional consumers. The research was made from in depth interviews with both types of consumers. The loyal consumers are called "Louquitos", as in crazy in Portuguese. This is due to the fact that these consumers are members of a fan group called "Loucos por Shoptime", translated to crazy for Shoptime, in various social medias. The called traditional consumers are other Casa \& Conforto's clients. The interviews enabled comparison between these two groups' perception, attitude, and motivation

Keywords: Perception, Attitude, Motivation, Loyalty, Casa \& Conforto, Shoptime. 
Sumário

1 INTRODUÇÃO

1.1. Objetivo do Estudo 8

1.2. Delimitação do Estudo 8

1.3. Relevância do Estudo 9

2 REFERENCIAL TEÓRICO 10

2.1. Percepção do Consumidor 10

2.1.1 Exposição 11

2.1.2 Atenção 12

2.1.3 Interpretação 13

2.2. Atitudes do Consumidor 14

2.2.1 Componentes da Atitude 15

2.2.2 Modelo de Hierarquia de Efeitos 16

2.3. Motivação do Consumidor 17

$\begin{array}{ll}\text { 2.4. Lealdade do Consumidor } & 19\end{array}$

3 METODOLOGIA DA PESQUISA 21

3.1. Tipo da Pesquisa 21

3.2. Seleção de entrevistados 21

3.3. Coleta de dados 23

3.4. Tratamento de dados 24

3.5. Limitações do Método 24

4 ANÁLISE DOS RESULTADOS 26

4.1. Percepção dos entrevistados sobre Casa \& Conforto 26

4.1.1. Percepção dos Consumidores Tradicionais 26

4.1.2. Percepção dos Consumidores Louquitos 27

4.1.3. Comparação das Respostas entre os Grupos de Entrevistados28

4.2. Atitude e Motivação dos entrevistados sobre Casa \& Conforto 29

4.2.1. Atitude e Motivação dos Consumidores Tradicionais 29 
4.2.2. Atitude e Motivação dos Consumidores Louquitos

4.2.3. Comparação das Respostas entre os Grupos de Entrevistados33

5 CONCLUSÕES E RECOMENDAÇÕES PARA NOVOS ESTUDOS 36

5.1. Recomendações Gerencias 38

5.2. Sugestões e recomendações para novos estudos 40

6 REFERÊNCIAS BIBLIOGRÁFICAS

$\begin{array}{ll}\text { Apêndice } 1 & 46\end{array}$

$\begin{array}{ll}\text { Apêndice } 2 & 48\end{array}$ 


\section{Lista de figuras}

Figura 1: Visão geral do processo perceptivo 11

Figura 2: Componentes e manifestações da atitude 15

Figura 3: Tipos de Lealdade 19

\section{Lista de Tabelas}

Tabela 1: Perfil dos consumidores Louquitos entrevistados

22

Tabela 2: Perfil dos consumidores tradicionais entrevistados 


\section{INTRODUÇÃO}

Como Morais (2011) afirma, ter clientes leais é o maior desejo de qualquer empresa. Todavia, esse comportamento mostra uma tendência de diminuir cada vez mais. Em um estudo realizado em 2019 pela Nielsen, é demonstrado que apenas $5 \%$ dos consumidores brasileiros se declaram super leais a marcas, canais de varejo ou produtos. Ademais, as marcas líderes em cada segmento são as que mais sofrem com essa deslealdade (LIMA, 2020). A líder da Indústria de Alimentos da Nielsen Brasil, Cristina Alvarenga, acredita que a principal razão para isso seja a rotina dinâmica dos consumidores e o ambiente de consumo que incentiva a troca ou experimentação (LIMA, 2020). Essa hipótese vai em linha com os dados levantados pela Global Disloyalty de que menos de $20 \%$ dos consumidores brasileiros tendem a ter uma marca favorita e 42,8\% dos brasileiros "amam experimentar produtos novos" (PEZZOTTI, 2019).

Por isso, um conceito que está cada vez mais frequente no cotidiano de empresas é o brand equity. Esse conceito é considerado o valor adicional que é atribuído a uma marca e que pode influenciar o pensamento dos consumidores em relação a ela (RIBEIRO, 2015). De acordo com Aaker (1991), a lealdade corresponde, na maior parte das vezes, ao núcleo do brand equity. Assim, marcas procuram aumentar seu brand equity para que os consumidores se tornem leais à elas e tenham preferência sobre os concorrentes, independente de outros fatores, como preço, conveniência e recursos (RIBEIRO, 2015).

Para Tavares (2003), quanto maior for a percepção desse valor adicional de uma marca, menor será o risco sofrido e maior será sua preferência. Assim sendo, diante de produto da concorrência com características, preço e conveniência melhores do que o seu, seus clientes leais vão preferir a sua marca (AAKAR, 1991), pois o consumidor leal a uma marca acredita que essa não deixa nada a desejar (SANTOS, 2017).

A fidelidade à marca pode trazer benefícios, como o aumento financeiro, visto que os clientes leais geralmente realizam compras com um ticket médio mais alto e a captação de novos clientes de forma orgânica e gratuita (GABRIEL, 2018). Além disso, se não houver essa retenção de clientes, a empresa gastará um valor alto recorrentemente para atrair uma nova série de clientes, o que pode 
custar cinco vezes mais caro do que manter a satisfação da sua base de clientes atual (HANHAN, 2018). Da mesma forma, uma marca com clientes leais tem maior margem de aceitação de erros, mais reconhecimento e melhor proteção contra condições do mercado (LOPES, 2020).

No caso da Shoptime, empresa que será analisada no presente estudo, os seus consumidores leais se intitulam "Louquitos". O Shoptime é o primeiro canal brasileiro de vendas pela TV e opera via internet, mobile, catálogo e televendas. Desde o seu lançamento em 1995 até hoje, conquistou milhões de consumidores, se tornando o primeiro canal de home shopping do Brasil (AMERICANAS MARKETPLACE, 2021). O sortimento da Shoptime tem ênfase nos produtos para casa, com três marcas próprias: Casa \& Conforto, Fun Kitchen e La Cuisine. A primeira marca é a maior dentre as três, está comercializa apenas itens de cama, mesa e banho. A segunda marca é de eletroportáteis e a última é de utilidade domésticas.

Os consumidores leais carinhosamente conhecidos como "Louquitos" surgiram a partir da criação da fanpage no Facebook chamado "Loucos por Shoptime", no qual atualmente tem quase quatro mil membros. Para enviar sua solicitação de filiação ao grupo, você precisa responder a uma série de perguntas, que incluem: "tem conhecimento que este grupo é somente para fãs do canal e apresentadores do Shoptime?" e é necessário aceitar as regras do grupo, que proíbe qualquer tipo de postagem que não seja relacionado aos produtos Shoptime. No grupo, os clientes postam fotos de seus produtos, recomendações, dicas, curiosidades sobre os apresentadores e perguntas divertidas para descontrair. A comunidade cresceu tanto que se expandiu para outra rede social, o Instagram, na qual o perfil @Loucos_Por_Shoptime já tem quase mil seguidores.

Para as três marcas do Shoptime, esses consumidores leais são uma ferramenta importante para manter o engajamento. A fidelidade é uma dimensão importante no relacionamento entre empresa e cliente (GABRIEL, 2020). Principalmente na era de redes sociais, uma comunidade que compartilha dicas e recomendações de seus produtos, se torna muito valiosa (MORAIS, 2011). Pensando nisso, em homenagens aos "Louquitos", a marca Casa \& Conforto, que vende itens de cama, mesa e banho, criou um jogo de toalha com as cores do canal especialmente para o aniversário do Shoptime, em abril 2021, o qual se chama "Loucos por Shoptime".

Todavia, a empresa não tem conhecimento se esses clientes leais são um benefício ou um maleficio para os demais consumidores. Casa \& Conforto está 
apostando ao alimentar ainda mais a comunidade dos "Louquitos", porém, não tem dados que demostrem a reação dos consumidores tradicionais perante a essa ação. Da mesma forma, ao assumir essa posição, a empresa pode estar desencorajando clientes tradicionais de realizarem sua compra. Ademais, pouco se sabe na literatura de marketing, sobre as semelhanças e as divergências na percepção, atitude e motivação entre os consumidores "tradicionais" e os leais da mesma marca. Logo, são notáveis a complexidade e a necessidade da pesquisa, uma vez que há poucas informações sobre o assunto.

\subsection{Objetivo do Estudo}

Portanto, o presente estudo tem o objetivo de analisar e comparar a percepção, a motivação e a atitude de consumidores leais e consumidores tradicionais da marca Casa \& Conforto do Shoptime.

\subsection{Delimitação do Estudo}

Este estudo volta-se mais especificamente para abordar a questão de analisar a percepção, motivação e atitude de consumidores leais e consumidores tradicionais, ou seja, aqueles que não são leais a marca, da marca Casa \& Conforto. Além disso, de acordo com uma pesquisa levantada pela Verint, podemos ver que a demanda por um modelo híbrido, sem e com interação humana, está crescendo (LULIO, 2019). Logo, Casa \& Conforto é uma marca que oferece isso, haja visto seu serviço de e-commerce e programa ao vivo na TV. Outrossim, o atendimento é um fator importante para gerar lealdade (MORAIS, 2011). É possível analisar que os programas ao vivo são o diferencial da marca para expor seus itens visto que os apresentadores tiram dúvidas dos clientes em tempo real, diminuindo os riscos percebidos durante o segundo estágio da tomada de decisão de compra do consumidor (SOLOMON, 2011). Ademais, em um estudo realizado pela empresa de análise de dados, Verint, em 2019 relata que no Brasil 59\% dos clientes afirmam que a conveniência é mais importante que o preço no momento da escolha (LULIO, 2019). Logo, podemos dizer que os clientes de Casa \& Conforto são mais propensos a serem leais à marca visto que os programas ao vivo facilitam o contato com o consumidor, aumenta a conveniência do processo de compra, o que os tornam mais engajados. 
Embora relevante, não se pretende tratar da questão das outras marcas próprias do canal Shoptime, La Cuisine e Fun Kitchen. Justamente para focalizar em um setor de produtos, foi determinado que apenas será realizado a análise dos consumidores de cama, mesa e banho, também conhecido como cameba. Como a marca é a maior dentre as três marcas próprias do Shoptime em relação ao seu sortimento, Casa \& Conforto oferece mais amostragem para investigação. Da mesma forma, a marca Casa \& Conforto tem um programa de televisão com seu nome, no qual apenas é exposto itens da marca. Logo, os consumidores têm mais reconhecimento de quais itens são dessa marca, facilitando a análise dos dados a serem coletados.

\subsection{Relevância do Estudo}

As informações que esse estudo pretende produzir podem se mostrar de interesse diretamente para o time comercial de Casa \& Conforto, que pode utilizar a informação para elaborar estratégias visando o aumento de vendas, seja incentivando ou não a influência dos consumidores leais sobre os tradicionais. Embora a investigação não considere as vendas das linhas de produtos de La Cuisine e Fun Kitchen, as outras marcas próprias do Shoptime podem aplicar os resultados da pesquisa em seu cotidiano comercial. As informações a partir desse estudo são proeminentes para as outras duas marcas visto que os "Louquitos" são consumidores do Shoptime em geral, e não apenas da marca Casa \& Conforto. Logo, seus consumidores fazem parte do grupo analisado e podem criar estratégias baseado em seu comportamento.

De um modo geral, os resultados a serem alcançados também poderão ser úteis para empreendedores e administradores em cargos mais voltados a dinâmica comercial e que têm a responsabilidade de criar produtos ou coleções. A investigação do comportamento do cliente pode trazer insights para outras empresas que não apenas vendam produtos dentro do setor cama, mesa e banho, mas que tenham consumidores fiéis, independente do ramo. 


\section{REFERENCIAL TEÓRICO}

Neste capítulo, é apresentado o referencial teórico do estudo. Está dividido em quarto partes, que abordam, respectivamente, a questão da percepção do consumidor, a atitude do consumidor, a motivação e a lealdade do consumidor.

\subsection{Percepção do Consumidor}

O conceito de percepção do consumidor tem várias definições. Percepção pode ser considerada 0 ato de tomar conhecimento de um objeto real (PAIM, 1993). Para Solomon (2011), a percepção é um processo de seleção, organização e interpretação das sensações que, por sua vez, são consideradas as reações imediatas dos cinco receptores sensoriais - visão, audição, paladar, olfato e tato - a estímulos básicos, como por exemplo cor, luz, som, textura, cheiro e sabor. Ou seja, percepção é o processo pelo qual pessoas entendem objeto a partir de um estímulo sensorial, englobando sensações, expectativas e experiências do indivíduo (KOTLER; KELLER, 2012).

Robbins, Judge e Sobral (2010) também expõem suas visões a respeito do conceito de percepção sendo algo que o indivíduo compreende a partir de impressões sensoriais, visando obter sentido ao seu ambiente. Dessa forma, os autores implicam que a percepção é algo que pode destoar da realidade objetiva. Isso pode acontecer devido a diversos fatores, tais como aspectos intrínsecos de quem percebe, visto que cada indivíduo tem suas próprias motivações, interesses, experiencias, expectativas, atitudes e personalidade. Além de questões do perceptor, fatores no objeto percebido e o contexto podem afetar a divergência entre a percepção do indivíduo e a realidade (SOLOMON, 2011).

A Figura 1, a seguir, demonstra a visão geral do processo perceptivo. 
Figura 1 - Visão geral do processo perceptivo

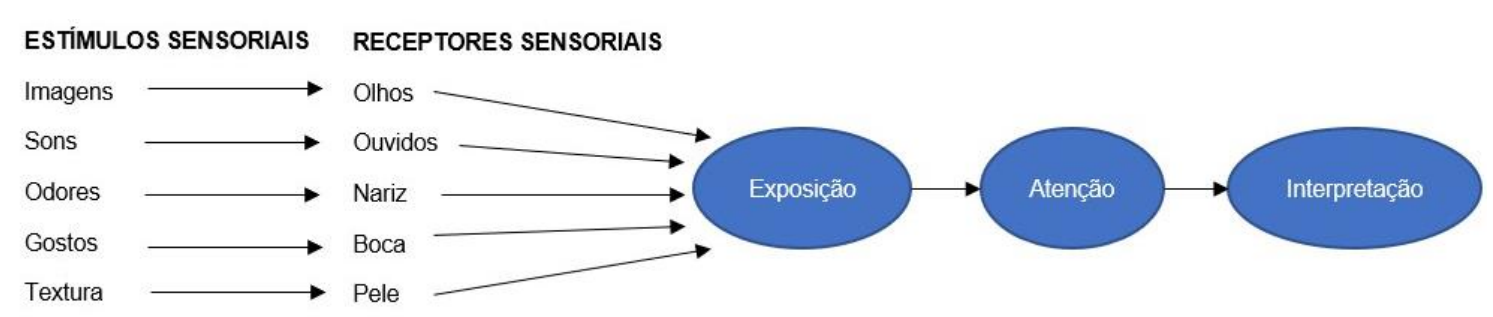

Fonte: Solomon (2011)

Para explicar a figura acima, Hawkins, Mothersbaugh e Best (2007) ilustram a ideia de que a percepção é constituída de três estágios: Exposição, Atenção e Interpretação.

\subsubsection{Exposição}

A primeira etapa ocorre quando o consumidor é exposto ao estímulo externo e seus receptores sensoriais são incitados, causando o primeiro contato do indivíduo com aquele estímulo e provocando seu sistema nervoso. Para exemplificar, isso ocorre quando um indivíduo sente o cheiro de café ao passar perto de uma cafeteria ou escuta o jingle de uma marca. Pode-se dizer que esses estímulos têm a limiar acima do absoluto, ou seja, esses têm o nível mínimo de sinais necessários para serem detectados pelos sentidos dos indivíduos (SILVA; ROZESTRATEN, 2018). Um exemplo de estímulos que estão acima do limiar absoluto é quando uma propaganda comercial televisiva tem sons ou cores chamativos, que atraem o indivíduo, como uma propaganda de supermercado no qual o locutor grita os preços enquanto os produtos são demonstrados na tela atrás de um background colorido.

Os autores psicofísicos também explicam que há o limiar terminal, que seria o maior valor do estímulo percebido, e o limiar diferencial, que seria a capacidade sensorial de perceber divergências entre pelo menos dois estímulos (SILVA; ROZESTRATEN, 2018). Conceitos como estes são importantes quando marcas resolvem alterar seu logo ou embalagens, levando em consideração sua identidade visual. Importante notar que, quando um estímulo não é percebido pelo consumidor, esse não alcança a percepção subliminar (SOLOMON, 2011). As mensagens subliminares podem ser sonoras ou visuais, como, por exemplo, esse ano a artista Luísa Sonza confessou que diz algo ao contrário no começo 
de sua nova música Intere\$ \$eira, levando o público freneticamente ouvir a faixa (FEFLETO, 2021), aumentando a mídia espontânea do seu novo álbum Doce 22.

\subsubsection{Atenção}

A segunda etapa do processo de percepção é a atenção. Isso ocorre quando o indivíduo precisa delimitar seu foco em apenas um estímulo específico. Em outras palavras, é quando os estímulos detectados pelos receptores sensoriais são processados pelo cérebro. O grau da atenção é influenciado por aspectos como fatores intrínsecos do receptor, fatores do próprio objeto percebido e contexto do ambiente (SOLOMON, 2011).

Importante notar que os consumidores se encontram em um estágio de sobrecarga sensorial (SOLOMON, 2011), assim dizendo, estão expostos a um número maior de estímulos do que efetivamente conseguem processar.

De acordo com Hoyer e Maclniss (2012), a atenção é atribuída a três características importantes: seletividade, divisão e limitação. Indivíduos determinam para onde querem direcionar sua atenção, dando mais importância para estímulos novos em comparação com aquilo que já entraram em contato outras vezes, logo, atenção é seletiva. Ademais, a atenção também pode ser dividida. Indivíduos conseguem parcelar sua atenção em unidades e utilizar para estímulos diferentes. Da mesma forma, a atenção é limitada, pois é apenas possível se concentrar em diversos recursos simultaneamente quando esse processamento não exigir muito esforço, for espontâneo e frequentemente praticado.

Outrossim, indivíduos também conseguem disponibilizar atenção e processar informações mesmo estando concentrado em outro estímulo, apenas utilizando sua percepção periférica, ou seja, fora de seu foco principal. Esse conceito é chamado de processamento pré-atencional (HELENE; XAIVER, 2003). Desse modo, é possível explicar a razão pela qual consumidores tendem a preferir uma marca que se encontra processada no modo pré-atencional do que outras marcas desconhecidas, apenas pelo nome (SOLOMON, 2011). Isso pode implicar que a marca já familiar ao consumidor convém um atributo de confiabilidade que a desconhecida não pode fornecer, mesmo que a segunda tenha melhores qualidades. Assim, o processamento pré-atencional consegue fornecer uma vantagem competitiva para uma marca no momento da decisão de 
compra, uma vez dito que é possível conquistar o consumidor apenas chamando sua atenção previamente (HOYER; MACLNISS, 2012).

\subsubsection{Interpretação}

Por fim, a última etapa do processo perceptivo do consumidor é a interpretação, que ocorre quando o indivíduo atribui significados aos estímulos sensoriais. Utilizando as recepções sensoriais, os estímulos são transmitidos em forma de impulsos elétricos até o sistema nervoso central, o qual processa as informações e as traduzem em sensações, gerando as respostas (BRITES, 2009), ou seja, a interpretação final do estímulo inicial. Segundo Hawkins, Mothersbaugh e Best (2007) e Robbins, Judge e Sobral (2010), igualmente às outras partes do processo perceptivo, essa última etapa também é influenciada pelas características do estímulo, da situação e do receptor, levando em consideração vieses interpretativos. Logo, indivíduos podem ter interpretações diferentes a partir do mesmo estímulo.

Outrossim, Solomon (2011) explica que o indivíduo atribui significados aos estímulos que provocaram os seus cinco sentidos e essa organização são baseadas em esquemas ou conjunto de crenças ao qual o estímulo é referente. $\mathrm{O}$ autor considera o processo de priming quando alguma característica de um estímulo remete a um determinado esquema, fazendo com que indivíduos analisem este da mesma forma que estímulos semelhantes de forma inconsciente. Assim, pessoas relacionam estímulos novos a outros que já foram armazenados na memória, dessa forma, acabam determinando como esse estímulo será interpretado. Segundo Solomon (2011), a interpretação vem a partir de um conjunto de estímulos, e não de um estímulo individual.

No mesmo princípio, existe a frase de Gestalt, a qual confirma que "o todo é maior do que a soma de suas partes". Como a ideia de Solomon (2011), a intepretação de um estímulo é determinada por uma série de outros já armazenados. O autor afirma que em Gestalt há três princípios que explicam a organização do estímulo: complementação, similaridade e figura-fundo. O primeiro diz respeito a quando pessoas tendem a preencher lacunas com a finalidade de completar uma imagem incompleta. O segundo princípio ocorre quando indivíduos procuram agrupar objetos que compartilham aspectos físicos parecidos. Por fim, o terceiro princípio, o de figura-fundo, que explica que algumas características do estímulo irão predominar, sendo a "figura", e outros aspectos ficarão em segundo plano, ou seja, o "fundo". 
Portanto, é possível ressaltar que a percepção é algo que carrega um significado ao indivíduo e não necessariamente corresponde com a função do objeto analisado. É importante entender a percepção dos consumidores e futuro consumidores, pois é esse aspecto que posiciona uma marca perante seus concorrentes no mercado (HAWKINS; MOTHERSBAUGH; BEST, 2007).

\subsection{Atitudes do Consumidor}

O conceito de atitude do consumidor tem várias definições dentre a literatura de administração de empresas. Segundo Hawkins, Mothersbaugh e Best (2007, p.200), "atitude é uma organização duradoura de processos motivacionais, emocionais, perceptivos e cognitivos em relação a algum aspecto do nosso ambiente. É uma predisposição adquirida para agir de modo constantemente favorável ou desfavorável em relação a determinado objeto". Ou seja, atitude é uma avaliação duradoura e genérica sobre objetos, problemas, anúncios e indivíduos, que podem ser denominadas de objeto de atitude. Atitude é considerada uma predisposição da forma de como indivíduos vão reagir, seja de forma favorável ou desfavorável, a algum determinado objeto (PETER; OLSON, 2009). Em outras palavras, é o modo como pessoas avaliam e agem perante um objeto.

Há quatro principais funções da atitude: utilitária, ego-defensiva, expressiva de valor e conhecimento (HAWKINS; MOTHERSBAUGH; BEST, 2007). A primeira diz respeito à tendencia de indivíduos a terem atitudes favoráveis a objetos que lhe tragam benefícios e obterem uma atitude desfavorável aos que não oferecem recompensas. A função ego-defensiva ocorre quando um indivíduo tem uma atitude favorável a um objeto que irá o proteger de algo que é inseguro, de forma que consigam proteger seu ego de ameaças. A terceira função, expressiva de valor, tem a finalidade de expressar os valores e a autoimagem do indivíduo. Importante ressaltar a diferença entre expressar quem o indivíduo é ou quem ele deseja ser, a segunda opção se encaixa em ego defensiva. Por fim, a última função, a de conhecimento, serve para despertar interesse em aprender mais sobre um assunto, para que o indivíduo possa organizar se irá corresponder com uma atitude positiva ou negativa. Importante ressaltar que uma única atitude pode exercer diversas funções.

Conforme Hawkins, Mothersbaugh e Best (2007) explicam, entender as atitudes dos consumidores é essencial, uma vez dito que esta está diretamente 
relacionada ao comportamento de compra. O modo pelo qual indivíduos entendem e expressam suas atitudes sobre um produto expõe características importantes sobre o estilo de vida desses. Assim, profissionais de marketing tentam alterar o comportamento de consumo de indivíduos a partir de uma mudança na atitude deles perante algum objeto, a fim de conquistar uma atitude mais favorável para aumentar as vendas. Contanto, como Solomon (2011) explica, é importante identificar e entender a razão por trás da função da atitude de um indivíduo antes de tentar alterá-la.

\subsubsection{Componentes da Atitude}

Segundo Hawkins, Mothersbaugh e Best (2007), a atitude é integrada por três componentes. Quando um indivíduo recebe algum estímulo, os três componentes são encadeados com a finalidade de conduzir a atitude que este terá sobre um objeto que principiou o estímulo. $O$ modelo $A B C$ das atitudes explica esses componentes e a relação entre eles. A seguir, na Figura 2, é possível entender esse fluxo com o diagrama.

Figura 2 - Componentes e manifestações da atitude

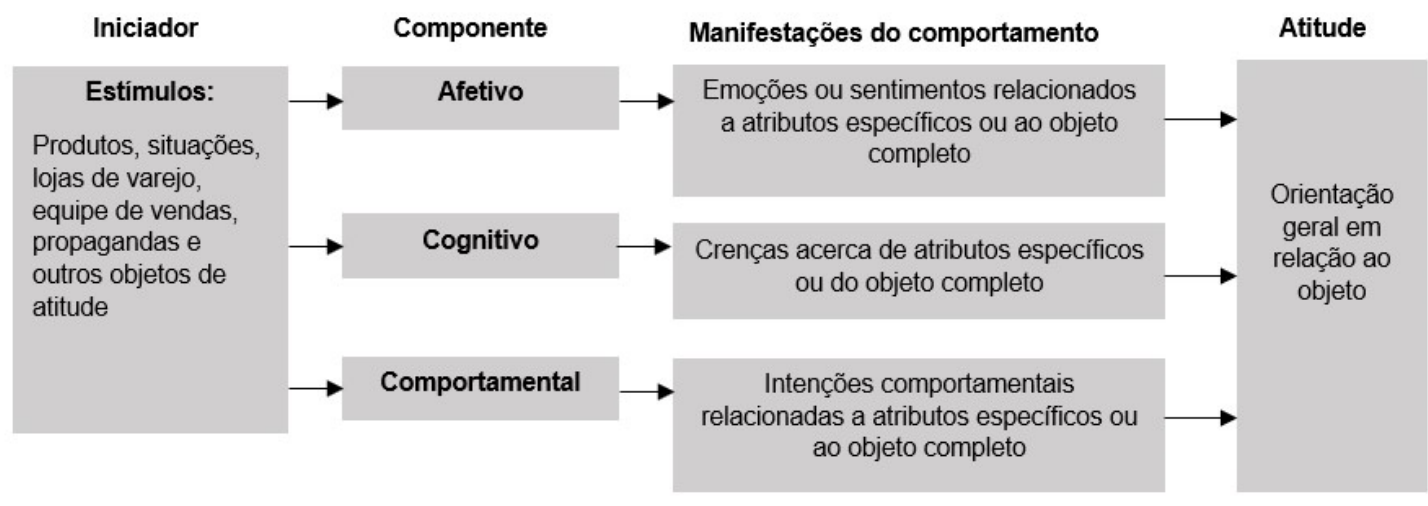

Fonte: Hawkins, Mothersbaugh e Best (2007)

Os três componentes da atitude são afeto (affect), comportamento (behavior) e cognitivo (cognition) que foram as siglas $\mathrm{ABC}$ do modelo. O primeiro componente é relacionado aos sentimentos e às emoções do consumidor perante algum produto ou serviço, que orienta o indivíduo a sentir. $O$ segundo componente, o comportamental, é referente à ação que um indivíduo tem sobre alguma atividade. Ou seja, esse componente verifica as intenções desse individuo ao reagir a algum objeto de atitude. Isso não apenas está relacionado com a decisão de compra, mas também com o interesse do indivíduo pela marca (HAWKINS; MOTHERSBAUGH; BEST, 2007). Por fim, o terceiro componente é 
o cognitivo, e está associado às crenças que o indivíduo tem a respeito do que ele acredita ser verdadeiro sobre um objeto (AVERY et al. 2010). Esse componente está análogo ao ato de conhecer.

\subsubsection{Modelo de Hierarquia de Efeitos}

Dependendo dos componentes percorridos no Modelo $A B C$, a atitude pode ser concebida de diversas maneiras, uma vez dito que decorre a partir da forma com que o modelo de hierarquia de efeitos estiver estabelecido.

Conforme a sequência dos três componentes, o modelo de hierarquia dos efeitos direciona uma atitude a ser tomada (PETER; OLSON, 2009). Como há três componentes, existem três hierarquias diferentes: aprendizagem padrão, baixo envolvimento e experiencial (AVERY et al., 2010). A primeira segue a ordem de cognição, afeto e comportamento, na qual indivíduos conhecem um objeto baseando em atributos tangíveis, depois desenvolvem um sentimento perante aquele e por fim realizam ou não a compra dele. Essa hierarquia é dita por ter um alto envolvimento, a atitude é baseada no processo de informações cognitivas.

A segunda hierarquia em questão, a de baixo envolvimento, como o nome implica, ocorre quando o cliente não tem uma predisposição a escolher uma das marcas por preferência e tem sua atitude após a compra de um produto. Dessa forma, o consumidor realiza sua compra a partir do pequeno conhecimento que já tem sobre as marcas expostas (comportamento), depois formam um sentimento desse objeto (afeto) e finalmente adquirem mais informação sobre o item comprado (cognição). Na hierarquia de baixo envolvimento, a atitude é baseada em processos de aprendizagem comportamental, que são as experiencias após a decisão de compra do consumidor que reforçam sua escolha inicial.

Por fim, o terceiro tipo de hierarquia é a experiencial na qual a atitude é formada a partir de atributos intangíveis, como o nome da marca. O consumidor tem algum sentimento desenvolvido por uma marca (afeto) e isso Ihe influencia a realizar uma compra de produto desta (comportamento) e a partir dessa aquisição, forma uma crença sobre o objeto (cognição). Ou seja, a atitude é baseada no consumo hedônico, isto é, no prazer a partir da interação do consumidor e produto.

Outrossim, é importante ressaltar que há níveis de envolvimento de uma atitude, ou seja, os consumidores realizam a decisão de determinar o quão 
comprometidos estão com uma atitude (SOLOMON, 2011). Existem três níveis de envolvimento: internalização, identificação e condescendência. As atitudes nas quais indivíduos estão altamente envolvidos são as internalizadas, ou seja, as atitudes se tornaram valores. Essas atitudes internalizadas são difíceis de mudar uma vez que são de extrema importância para o indivíduo. Dessa forma, podemos dizer que consumidores fanáticos se encaixam nesse nível de envolvimento. As atitudes de identificação são aquelas nas quais permitem uma adequação social do indivíduo para que esse esteja em conformidade a um grupo, assim se tornam de médio envolvimento. Enquanto isso, as de menor nível de envolvimento e as mais superficiais são as de condescendência, uma vez que são tomadas ponderando sua consequência, ou seja, a fim de receber benefícios ou evitar punições.

Há uma teoria que deve ser ressaltada: a Teoria do Julgamento Social. A ideia implica que indivíduos são influenciados a tomar uma atitude sobre um objeto baseado no conhecimento prévio sobre aquele item (PRIMO, 2014). Ou seja, o grau de rejeição ou aceitação a partir de uma informação nova de um objeto de atitude varia de acordo com as informações que o indivíduo já tinha perante aquele objeto. Como exemplo, um indivíduo tem algum objeto de uma marca específica, portanto, ele assimila que deve gostar de outros produtos daquela marca também. Assim, é possível notar que essa teoria expõe a atitude de um consumidor fiel a alguma marca, na qual desenvolve fidelização às marcas e maior tolerância a mudanças.

\subsection{Motivação do Consumidor}

O conceito de motivação pode ser definido como os processos que explicam o comportamento de indivíduos (SOLOMON, 2011). A motivação é uma força, ocasionada por um estado de tensão, devido a uma necessidade não satisfeita, que impulsiona o indivíduo a tomar a alguma ação, que tem a finalidade de suprir essa necessidade (SOLOMON, 2011). As necessidades podem ser classificadas em fisiológicas e psicológicas. A primeira é a mais fácil de identificar, ela se refere às necessidades biológicas, como alimento, água, oxigênio, roupas dentre outros. As necessidades psicológicas se referem ao ambiente, sociedade e cultura que o indivíduo está inserido, como aceitação, poder e status (SCHIFFAMAN; KANUK, 2000).

As necessidades também podem ser classificadas em outras duas categorias: utilitárias e hedônicas. De acordo com Solomon (2011), a primeira é 
relacionada com a busca do indivíduo a querer obter algum benefício funcional através das características tangíveis de um produto ou serviço. Em contrapartida, as necessidades hedônicas são aquelas de cunho emocional, no qual envolvem a experiencia e expectativa do consumidor de um produto ou serviço ser capaz de satisfazer necessidades psicológicas, como alegria, status entre outros.

Como dito anteriormente, a motivação é causada por um estado de tensão que impele o indivíduo a recorrer a algum comportamento para suprir essa necessidade. Esse estado de tensão chamado de impulso é ocasionado devido a uma separação do estado ideal, a meta do consumidor, pois o indivíduo repara que está necessitado de algo e precisa buscar supri-la. Quanto maior a tensão, ou seja, o espaço entre a necessidade e a pessoa, maior a urgência de reduzi-la (SOLOMON, 2011).

Outrossim, há vários fatores que podem afetar a motivação de um consumidor e a maneira na qual ele vai suprir essas necessidades. Segundo Solomon (2011), esses fatores podem variar entre experiencias, valores, cultura, ambiente social e outros. Outro fator que persuade nessa decisão é a percepção que o indivíduo tem de si. Os produtos que alguém possui, gostaria de ter ou não quer são frequentemente associados com o reflexo da autoimagem do indivíduo (SCHIFFAMAN; KANUK, 2000).

Ademais, a motivação pode ser positiva ou negativa, em outros termos, ela pode ter como objetivo conduzir ou afastar um indivíduo de certo objeto (SOLOMON, 2011). Uma meta positiva é influenciar o indivíduo a se aproximar de algo ou alguma condição. Por outro lado, uma meta negativa procura proteger e evitar o encontro do indivíduo com certa situação. Assim, Solomon (2011) identificou os três conflitos motivacionais, que são os resultados distintos fruto da consequência das escolhas que os consumidores fazem.

O primeiro conflito motivacional é a Aproximação - Aproximação, ela ocorre quando o consumidor escolhe entre duas opções favoráveis. Ambas as opções têm qualidades e pontos negativos, assim, ao fazer uma decisão entre as duas, o consumidor perde ao adquirir as características ruins do produto escolhido e não obter os benefícios do produto não escolhido. Isso pode levar o consumidor a procurar mais razões para ter escolhido um produto ao outro, colocando mais defeitos no produto não escolhido quando não necessariamente essas características verdadeiramente afetam o consumidor.

O segundo conflito é denominado de Aproximação - Evitação. Nesse caso, o indivíduo ao mesmo tempo que deseja certo produto, também o procura evitar. 
Isso ocorre quando algum objeto, mesmo sendo desejado, tem consequências negativas, despertando um sentimento de culpa e desconforto no indivíduo ao adquiri-la. Um exemplo desse conflito é a compra e consumo de um chocolate quando o indivíduo está procurando emagrecer.

Por fim, o último conflito é o de Evitação - Evitação, na qual o indivíduo precisa escolher entre duas opções indesejadas, ou seja, com atributos ruins. Uma situação no qual esse conflito pode ocorrer é a decisão entre ficar doente ou sentir dor da vacina.

\subsection{Lealdade do Consumidor}

Um indivíduo considerado um consumidor leal é caracterizado não apenas pelo seu comportamento, a repetição de compra, mas também por suas questões psicólogas (JACOBY; CHESTNUT , 1978). A lealdade não pode ser apenas representada pela alta incidência de recompra, uma vez que lealdade é um construto multidimensional, pois apresenta dimensões como acessibilidade, confiabilidade, emoções e sentimentos (ELLIS, 2000; DICK; BASU, 1994).

Uma das definições do conceito de lealdade é o grau de uma atitude positiva de um consumidor, por meio da qual este apresenta vínculo emocional e tem intenção de recompra (MOWEN; MINOR, 1998). De acordo com Oliver (1999), um consumidor leal apresenta um comprometimento profundo em favorecer uma marca no futuro, não obstante esforços de marketing e fatores situacionais podem influenciar para ocasionar um comportamento de troca. Logo, lealdade é uma resposta comportamental a partir de uma tomada de decisão levando em consideração mais de duas marcas, na qual esse comportamento implica compras repetidas baseada em fatores que são os mesmos componentes da atitude: cognitivos, afetivos e disposicionais (LARÁN; ESPINOZA, 2004).

Ao analisar os dois principais fatores de lealdade, o comportamento de recompra e a atitude do consumidor, é possível perceber quatro situações de lealdade que podem ser vistas na figura a seguir.

Figura 3 - Tipos de Lealdade

\begin{tabular}{llc|c|}
\multicolumn{2}{c}{} & \multicolumn{2}{c}{ Comportamento } \\
\multirow{4}{*}{ Atitude } & Forte & Fraco \\
\cline { 3 - 4 } & Fraco & Lealdade Verdadeira & Lealdade Latente \\
\cline { 3 - 4 } & & Lealdade Falsa & Sem Lealdade \\
\cline { 3 - 4 } & &
\end{tabular}

Fonte: Dick e Basu (1994) 
Os quatro tipos de lealdade são: lealdade verdadeira, lealdade falsa, lealdade latente e sem lealdade. A primeira situação, lealdade verdadeira, além de conter um índice de recompra, é caracterizado por um forte comprometimento do consumidor. É o nível mais alto de lealdade. Em contrapartida, a lealdade falsa ocorre quando há recompra, porém, não há comprometimento e preferência pela marca específica. Ou seja, outros fatores estão impulsionando a compra desse produto, como por exemplo, preço baixo ou conveniência (LARÁN; ESPINOZA, 2004). Esses consumidores são os propensos a trocarem de marca de acordo com os melhores benefícios oferecidos a ela, sem preferência.

O terceiro tipo de lealdade, a lealdade latente, há um forte vínculo emocional com uma marca, mas não há recompra. Isso pode ocorrer devido a barreiras de acesso, como preço mais caro do que o consumidor está disposto a pagar ou falta de produtos disponíveis perto da localidade desse consumidor (LARÁN; ESPINOZA, 2004). A lealdade latente pode ser caracterizada também por aquele consumidor que tem admiração pelos valores de uma marca, mas não é o público-alvo do produto oferecido por ela.

Por fim, um consumidor considerado não leal é aquele que tem um baixo comportamento e uma baixa atitude, ou seja, tem uma relação com uma marca específica, mas não realizam compras regulares e não tem preferência por ela.

No mundo corporativo, clientes leais são uma conquista, pois geram vários benefícios, como menores custos em comparação a atração de novos clientes, maior poder de barganha com fornecedores e a possibilidade de praticar preços maiores do que a concorrência (FERNANDES, 2020).

Além das vantagens, consumidores leais também são considerados uma conquista para empresas devido à sua crescente dificuldade na fidelização de clientes. Quanto mais experientes digitalmente um consumidor se torna, menos leal e mais independente ele se torna perante às grandes marcas do varejo devido a uma maior disponibilidade de alternativas de marcas (CARDOSO, 2019). 


\section{METODOLOGIA DA PESQUISA}

Neste capítulo, pretende-se apresentar informações sobre as diversas decisões as quais concerne à metodologia da pesquisa. Está divido em cinco sessões, que informam, respectivamente, sobre o tipo da pesquisa, a seleção dos entrevistados, os procedimentos da coleta de dados, o tratamento dos dados e as limitações da metodologia escolhida.

\subsection{Tipo da Pesquisa}

Nesse presente estudo, foi realizada uma pesquisa exploratória e qualitativa. Segundo Zikmund (2006), a pesquisa exploratória é recomendada quando há poucas informações sobre um fenômeno. Assim, pesquisas exploratórias têm a finalidade de oferecer maior conhecimento sobre determinado assunto (GIL, 2008). Uma vez que há escassas investigações sobre o comportamento do consumidor da marca própria do Shoptime, a Casa \& Conforto, acredita-se que a pesquisa exploratória seja adequada para alcançar o objetivo do estudo.

Como dito anteriormente, além de exploratória, a pesquisa é qualitativa. Segundo Notess e Walker (2006), esse tipo de pesquisa permite uma maior interação entre entrevistado e entrevistador, possibilitando o investigador abordar alguns assuntos que vão além do que pesquisas quantitativas poderiam ir.

\subsection{Seleção de entrevistados}

Para seleção dos entrevistados desta pesquisa, foi realizada uma distribuição entre dois tipos de consumidores da marca Casa \& Conforto: os leais, que fazem parte do grupo "Loucos por Shoptime", denominados de "Louquitos", e os consumidores "tradicionais" da marca, que compram produtos Casa \& Conforto, mas não participam de grupos da marca. Em ambos os grupos, foram entrevistados sete consumidores, totalizando 14 indivíduos participantes da investigação. 
O primeiro grupo consistiu em apenas Louquitos, esses são os consumidores leais da marca Casa \& Conforto, que fazem parte de grupo nas redes sociais chamado "Loucos por Shoptime". Esses são consumidores que além de comprar frequentemente os produtos da marca, têm um forte vínculo emocional com este. Buscando entrar em contato com esse grupo, foram enviadas mensagens privadas para os que realizam publicações sobre produtos de cama, mesa e banho de Casa \& Conforto no grupo privado "Loucos por Shoptime". Além disso, também foi utilizada outra rede social para conseguir contato com mais Louquitos. Foram visualizados os comentários nas fotos e vídeos de itens de Casa \& Conforto no perfil do grupo no Instagram e enviada uma mensagem similar para esses indivíduos. Na Tabela 1, a seguir, é exposto o perfil dos entrevistados desse grupo.

Tabela 1 - Perfil dos Louquitos entrevistados

\begin{tabular}{|c|c|c|}
\hline Entrevistado & Idade & Tempo sendo consumidor de Casa \& Conforto \\
\hline $1 \mathrm{~A}$ & 43 anos & 17 anos \\
\hline $2 \mathrm{~A}$ & 58 anos & 20 anos \\
\hline $3 \mathrm{~A}$ & 56 anos & 20 anos \\
\hline $4 \mathrm{~A}$ & 62 anos & 10 anos \\
\hline $5 \mathrm{~A}$ & 32 anos & 20 anos \\
\hline $6 \mathrm{~A}$ & 58 anos & 20 anos \\
\hline $7 \mathrm{~A}$ & 46 anos & \\
\hline
\end{tabular}

Em relação ao segundo grupo de entrevistados, foram entrevistados consumidores "tradicionais", ou seja, aqueles que compram com frequência produtos de Casa \& Conforto, porém, não participam de grupos da marca. Está denominação de "tradicional" está relacionado com o fato de que eles são como consumidores tradicionais de qualquer marca, um consumidor padrão. Para esse segundo grupo de entrevistados, também foi utilizado as redes sociais, mais precisamente Whatsapp e Instagram para contactá-los. A maioria dos membros desse grupo foi localizada a partir dos comentários em publicações sobre os produtos Casa \& Conforto no Instagram oficial do Canal Shoptime. Dois membros são familiares da entrevistadora, assim, o contato foi estabelecido via mensagem de Whatsapp. Na Tabela 2, a seguir, são expostos os perfis dos entrevistados desse grupo. 
Tabela 2 - Perfil dos consumidores tradicionais entrevistados

\begin{tabular}{|c|c|c|}
\hline Entrevistado & Idade & Tempo sendo consumidor de Casa \& Conforto \\
\hline 1B & 56 anos & 2 anos \\
\hline 2B & 36 anos & 15 anos \\
\hline 3B & 40 anos & 20 anos \\
\hline 4B & 50 anos & 4 anos \\
\hline 5B & 50 anos & 1 ano \\
\hline 6B & 41 anos & 10 anos \\
\hline 7B & 49 anos & \\
\hline
\end{tabular}

\subsection{Coleta de dados}

A coleta de dados da pesquisa exploratória e qualitativa foi feita por meio de entrevistas em profundidade com os 14 entrevistados. Esse tipo de coleta é compreendido por uma entrevista semi-estruturada, direta e pessoal, no qual o entrevistado é encorajado a delatar suas motivações, atitudes, percepções e seus sentimentos sobre um determinado assunto (NOTESS; WALKER, 1996). Dessa forma, o entrevistador consegue interagir melhor com o entrevistado, de modo que seja possível extrair mais informações das previstas no roteiro.

A partir da revisão da leitura, foram desenvolvidos dois roteiros com 20 perguntas cada, um destinado aos Louquitos (Apêndice 1) e o outro aos consumidores tradicionais (Apêndice 2). Ambos os roteiros são idênticos até a pergunta 16 , sendo diferenciados a partir de então nas perguntas subsequentes. As perguntas sobre os Louquitos, a partir da décima sétima pergunta, são relacionados à sua participação no grupo, concomitantemente, para os tradicionais, as perguntas focam na sua percepção sobre o grupo em questão.

Como dito anteriormente, o contato com membros desse grupo foi estabelecido a partir de publicações no grupo "Loucos por Shoptime" no Facebook e Instagram. Com os que responderam e aceitaram participar, foram agendados horários para as entrevistas, feitas por meio de ligação telefônica ou ligação de vídeo pelo Zoom ou pelo Facebook dadas as condições de isolamento social provocado pela pandemia do Covid-19.

Em relação aos consumidores tradicionais, dois indivíduos dos sete consumidores tradicionais eram próximos à pesquisadora, assim, foram 
realizadas entrevistas pessoalmente. Os outros cinco consumidores foram contatados por meio dos comentários das fotos no Instagram do Canal Shoptime. Procurava-se nos pareceres em todas fotos e vídeos de produtos de Casa \& Conforto nas últimas semanas por pessoas que anunciavam que tinham comprado o produto ou outro item parecido. Para esses indivíduos, foi enviada uma mensagem perguntando se queriam participar da entrevista. Aos que responderam e aceitaram, foi realizada uma ligação telefônica ou chamada por vídeo pelo Instagram para que pudesse ser realizada a pesquisa.

\subsection{Tratamento de dados}

Todas as respostas foram compiladas em uma planilha do Microsoft Excel, dividida em duas abas de dois eixos cada. $\mathrm{Na}$ aba que se refere às respostas dos Louquitos, em um eixo há as perguntas e no outro estão as respostas. A segunda aba diz respeito às respostas dos consumidores tradicionais, e, igualmente à aba dos Louquitos, em um eixo estão as perguntas do roteiro da entrevista e em outro estão as respostas desse grupo. Dessa forma, os dados foram organizados de maneira que possibilitasse ao pesquisador comparar as semelhanças e divergências entre as respostas dentre o mesmo grupo de consumidores, buscando estabelecer um padrão em seu comportamento. Além disso, posteriormente, essa organização viabilizou uma análise entre os dois grupos, os Louquitos e consumidores tradicionais.

Outrossim, para facilitar mais ainda a análise dos dados, as perguntas foram etiquetadas com o assunto ao qual elas se referem, dividindo entre: perfil do entrevistado, percepção, atitude e motivação.

\subsection{Limitações do Método}

Embora a pesquisa exploratória e qualitativa seja a mais adequada para essa investigação, essa apresenta algumas limitações.

De acordo com Gil (2008), uma entrevista em profundidade apresenta algumas desvantagens, como fatores que afetam os entrevistados e consequentemente suas respostas, como falta de motivação, inabilidade de responder adequadamente, falha na interpretação das perguntas e respostas falsas. Outras desvantagens são a demora da coleta de dados, a maior complexidade de registrar, tratar e analisar as respostas e influência da opinião pessoal do entrevistador sobre as respostas e entrevistados. 
Segundo Zikmund (2006) consta, estudos considerados qualitativos limitam-se a uma pequena amostra de pessoas, pois apenas um seleto grupo é escolhido para realizar a entrevista profunda. Assim, é necessário se atentar a generalização, pois não é possível replicar a realidade do pequeno e escolhido grupo para a sociedade por completa.

Outras desvantagens de pesquisas qualitativas são em respeito à interpretação dos dados. Como o investigador chega à conclusão do estudo a partir de sua interpretação dos dados, o resultado não necessariamente consta a realidade (CRESWELL, 2003).

Ademais, outra desvantagem encontrada foi a dificuldade de agendar as entrevistas devido principalmente, ao obstáculo tecnológico que os consumidores de Casa \& Conforto tem. Da mesma forma, como a grande maioria dos meus entrevistados são desconhecidos, houve um contratempo ao marcar o horário das entrevistas uma vez dito que foi necessário conciliar os horários de trabalho, de outros afazeres e até mesmo dos programas ao vivo do Shoptime. 


\section{ANÁLISE DOS RESULTADOS}

O capítulo a seguir apresenta a análise dos dados coletados na pesquisa de campo. Ele é divido em duas seções a saber: a percepção dos entrevistados sobre Casa \& Conforto e suas atitudes e motivações perante a marca. As duas seções são subdividas em três subseções, de forma que são analisadas primeiramente as respostas dos Louquitos, posteriormente, a dos consumidores tradicionais e, por fim, a comparação entre os dois grupos.

\subsection{Percepção dos entrevistados sobre Casa \& Conforto}

Para avaliar a percepção dos entrevistados, foram feitas perguntas sobre esse assunto. Nelas, os indivíduos precisam compartilhar o que associam à marca Casa \& Conforto e ditar três palavras as quais representava a marca.

\subsubsection{Percepção dos Consumidores Tradicionais}

$\mathrm{Na}$ avaliação da percepção do que os consumidores tradicionais achavam de Casa \& Conforto, em geral, as palavras e os termos mais associados à marca eram relacionados ao seu preço e à sua qualidade. É notável que os consumidores tradicionais têm uma percepção de que a marca tem um bom custo-benefício. Segue abaixo o relato da Entrevistado 3B:

Sinto que existe uma ideia cultural de que esses canais de compra são voltados para atender os públicos mais ricos. Acho legal que Casa \& Conforto tem produtos $100 \%$ algodão e com preços muito acessíveis para as classes mais desfavorecidas também. $O$ preço deles é bem menor do que nas lojas físicas aqui da minha cidade!

Isso pode ser relacionado ao fato de que esses consumidores não têm tanta lealdade à marca, e, assim, costumam realizar pesquisas na concorrência e comparação de preços. Entrevistado 7B afirmou que sempre utiliza sites de comparações de preços antes de realizar qualquer compra, principalmente durante eventos grandes do varejo como a Black Friday. E ainda confere o preço de itens homólogos para avaliar se a promoção realmente compensa. Assim, é 
possível perceber que esse grupo não mede esforços para verificar os preços e qualidade dos produtos Casa \& Conforto em contraste com o da concorrência.

Outrossim, por consumir outras marcas e outros produtos, eles têm consciência da qualidade e do preço que a concorrência oferece, e, assim, conseguem verificar o custo-benefício de Casa \& Conforto. De acordo com Hawkins, Mothersbaugh e Best (2007), conseguir entender a percepção dos consumidores sobre uma marca é importante para se posicionar perante seus concorrentes no mercado. Deste modo, compreende-se que os produtos de Casa \& Conforto conseguem proporcionar qualidade pelo preço que têm.

\subsubsection{Percepção dos Consumidores Louquitos}

Analisando o retorno dos Louquitos, a associação da marca com os termos de "marca exclusiva" e "exclusividade" se destacou. Vários membros do grupo entrevistado tinham conhecimento que Casa \& Conforto é uma marca própria do Shoptime.

Nas respostas dos Louquitos, a palavra "família" também foi associada a Casa \& Conforto. Alguns argumentaram que a marca oferece opção para todos os membros da família, desde coleções voltadas para os mais idosos até infantojuvenis. Todavia, o conceito família também foi associado a Casa \& Conforto devido às experiências dos respondentes que já presentearam seus familiares com produtos da marca, assistiram ao programa da TV junto com seus familiares ou estavam presentes em momentos marcantes. A reposta da Entrevistada 4A se destacou nesse sentido.

Quando fiquei grávida, minha mãe veio morar comigo e assistíamos o programa na televisão todos os dias. Ela não tinha condições financeiras boas na época, mas juntou dinheiro por meses e me deu meu primeiro enxoval sete peças. Aquilo foi uma conquista.

Logo, é possível reparar que Casa \& Conforto está presente em momentos importantes para os Louquitos e as suas famílias. Principalmente para essa entrevistada, além de assistir aos programas na TV com sua família, a marca também é positivamente associada a um episódio emocional para ela. Dessa forma, a Casa \& Conforto ganha mais importância para esse tipo de consumidor.

Robbins, Judge e Sobral (2010) explicam que além dos fatores do próprio objeto percebido e contexto inserido, os aspectos intrínsecos do receptor também afetam a percepção de um indivíduo. Uma vez dito que cada entrevistado tem suas próprias motivações, interesses, experiências, 
expectativas, atitudes e personalidade, a percepção de um indivíduo pode se destoar dos outros e da realidade em si. Para os Louquitos, assistir aos programas de Casa \& Conforto e comprar produtos da marca remetem ao sentimento de estar com sua família, um sentimento acolhedor e de felicidade. Assim, suas percepções sobre a marca vão além de características do objeto e do contexto posto que, ao associar a marca a uma experiência positiva e de afeto de sua memória, as percepções são bastante afetadas por questões intrínsecas dos membros desse grupo.

\subsubsection{Comparação das Respostas entre os Grupos de Entrevistados}

Segundo Hawkins, Mothersbaugh e Best (2007), a percepção é algo que carrega um significado ao indivíduo e não necessariamente corresponde com a função do objeto analisado. A divergência do que Casa \& Conforto representa para os dois tipos de consumidores é bastante perceptível. Embora haja algumas semelhanças, as diferenças se sobressaem e são uma das razões pelas quais é possível distinguir cada tipo de consumidor.

Uma das semelhanças foi a associação com qualidade, os dois grupos valorizam esse aspecto da marca. De acordo com Hawkins, Mothersbaugh e Best (2007), associações de uma marca ou um produto estão relacionadas com aspectos intrínsecos do indivíduo como experiencias, crenças e valores. Ademais, essas associações conseguem fazem com que indivíduos consigam criar uma expectativa de objetos similares desconhecidos a partir dessas associações. Assim, os dois grupos de consumidores, mesmo não adquirindo todos produtos ou linha de produtos que a marca oferece, sabem que comprando Casa \& Conforto vão ter o benefício funcional de qualidade. Durante a entrevista com a Entrevistada 2B, ela narrou que não tem medo de comprar novos itens ou linhas de Casa \& Conforto, pois ela confia marca posto que nunca se aborreceu com a qualidade de nenhuma de suas compras.

Entretanto, uma das maiores diferenças percebidas foi o fato de que os Louquitos associaram muito mais às palavras "marca exclusiva" ou "exclusividade" a Casa \& Conforto do que os tradicionais. Isso pode ser um reflexo direto da divergência em relação à frequência na qual os consumidores tradicionais e os Louquitos assistem o programa da TV. Para os consumidores tradicionais, a maioria ainda assiste, mas não diariamente. Diferentemente, os Louquitos assistem pelo menos um programa por dia, como se fosse um compromisso em seu dia. Desse modo, é possível reparar que os Louquitos têm 
mais consciência do que é uma marca própria e que seus itens não são comercializados em nenhuma outra plataforma de varejo exceto as do Americanas SA justamente porque é bastante enfatizado pelos apresentadores como um apelo para estimular as vendas. Assim, é possível implicar que os Louquitos têm melhor conhecimento do conceito de marca própria e valorizam esse aspecto visto que os termos "exclusividade" e "marcas exclusivas" foram bastante associadas com Casa \& Conforto.

Outra diferença é que os consumidores tradicionais associaram a marca com características relacionadas ao seu preço, como "preço bom", "barato" e "acessível", enquanto os Louquitos praticamente não mencionaram. Podemos analisar que, para os consumidores tradicionais, a compra de um item Casa \& Conforto é uma compra de médio envolvimento, na qual há uma comparação de preço com o mercado e avaliações do produto e com os da concorrência. É possível notar que os Louquitos não têm esse mesmo comportamento, devido ao fato de comparem com mais frequência os produtos da marca. Também, é possível implicar que, como assistem com mais frequência aos programas de TV, já têm mais conhecimento dos produtos e por isso não precisam realizar muitas pesquisas. Outro fator que os programas de TV fazem é estimular a compra por impulso, então, acabam realizando a compra a partir dos apelos comerciais.

Como Robbins, Judge e Sobral (2010) sustentam, o processo perceptivo é influenciado pelas características do estímulo, da situação e do receptor, levando em consideração vieses interpretativos. Dessa forma, é possível afirmar que indivíduos podem ter interpretações diferentes a partir do mesmo estímulo. Logo, é entendível as divergências de percepção entre os dois grupos sobre a mesma marcam.

\subsection{Atitude e Motivação dos entrevistados sobre Casa \& Conforto}

Além de analisar a percepção dos dois grupos de consumidores da marca, também foram perguntadas questões para entender a atitude e motivação dos entrevistados.

\subsubsection{Atitude e Motivação dos Consumidores Tradicionais}

Os consumidores tradicionais têm como seu principal fator de decisão de compra a avaliação dos itens nos sites. Em geral, como esse grupo não assiste 
frequentemente aos programas de TV, esse fator não foi classificado como tão importante. Da mesma forma, os preços dos itens são questões que os consumidores tradicionais também avaliam, entretanto, como dito anteriormente, eles buscam o melhor custo-benefício, não necessariamente preços baixos. Como a Entrevistada 3B mencionou: "Olho o preço e a qualidade também, se fosse muito barato e de péssima qualidade, eu não compraria". Do mesmo modo, ao serem questionados de qual aspecto de Casa \& Conforto mais gostavam, "qualidade" foi a resposta mais replicada. Assim, isto se alinha com o fato de que prezam pela avaliação do item no site ao realizarem uma compra visto que as críticas dos produtos é um modo de verificar a qualidade do item. Da mesma forma, como visto anteriormente, os grupos entrevistados não medem esforços para garantir que não irão se arrepender de sua compra. Como a Entrevistada 6B afirmou:

Antes de comprar qualquer toalha, eu sempre olho tudo. Desde a ficha técnica para ver a gramatura, toalha engana muito. Chego a assistir resenhas no YouTube quando vou comprar um item mais caro como as de algodão egípcio.

Outrossim, os consumidores tradicionais foram questionados sobre sua opinião perante o grupo "Loucos por Shoptime" e os "Louquitos". De uma maneira geral, os consumidores tradicionais gostam dos Louquitos e acreditam que sua existência demonstra que Casa \& Conforto é uma marca de qualidade. A Entrevistada 1B até citou que "ajudam pessoas que não conhecem a marca a comprar". Entretanto, é possível notar que alguns consumidores tradicionais entrevistados gostam de manter a separação entre eles e os Louquitos. De certo modo, eles são vistos como "doidinhos" de uma maneira levemente pejorativa, pois acham cômico seu comportamento fanático.

Ao serem questionados se gostariam de participar do grupo "Loucos por Shoptime", um grupo disse que sim, entretanto, apenas com o intuito de acharem boas promoções e cupons. É possível reparar uma atitude perante o grupo com uma função utilitária, isto é manifestam atitudes favoráveis a objetos que lhe tragam recompensas e demonstram uma atitude desfavorável aos que não oferecem benefícios (HAWKINS; MOTHERSBAUGH; BEST, 2007). Os que se interessaram em participar estão em busca de recompensas monetárias ao "fuçar" por promoções. Da mesma forma, os que não desejaram entrar no grupo não enxergaram benefícios com essa oportunidade, e, então, não têm uma atitude favorável ao grupo. 
Por fim, os consumidores tradicionais foram requisitados para avaliar se eles seriam propensos a comprar um item caro e mal ou não avaliado no site, mas que foi bem comentado no grupo "Loucos por Shoptime". Nesse caso, a maioria respondeu que não. Os poucos que responderam sim argumentaram que comprariam apenas se os Louquitos postassem muitos comentários e fotos. Em outras palavras, os consumidores tradicionais são mais céticos quanto aos produtos do que os Louquitos, conforme o relato a seguir demonstra:

As pessoas do grupo podem estar inflamadas pelo hábito de comprar e usar os itens. Sinto que quem está avaliando pelo site, tem mais peso na sua crítica.

Dessa forma, essa citação sintetiza a razão por trás da decisão dos consumidores em não querer participar ou de participar apenas para conferir as promoções. Esse grupo de entrevistados não confia plenamente na opinião dos Louquitos devido ao seu fanatismo. Eles acreditam que o grande envolvimento com a marca é um fator negativo para a sua credibilidade visto que os Louquitos podem ser "cegos" aos pontos negativos, afetando seu senso crítico.

\subsubsection{Atitude e Motivação dos Consumidores Louquitos}

Em relação ao fator que mais influencia a decisão de compra dos Louquitos, o programa da TV foi classificado como o mais importante. Os Louquitos confiam nos apresentadores e acreditam que a interação deles com o público é essencial para sua compra. Esse grupo de entrevistados também argumenta que a seleção da grade da programação é a melhor forma de promoção do site; um entrevistado, por exemplo, metaforicamente comparou como um "pente fino". Da mesma forma, os Louquitos se sentem mais inclinados a comprarem quando há preço exclusivo para TV e televendas, pois sentem que é uma promoção limitada. Além das compras, os Louquitos assistem os programas da TV como um compromisso ou uma forma de entretenimento. Segue a citação da Entrevistada 3A como exemplo:

As vezes estou pra baixo e aparece a Fabiana (apresentadora do Canal Shoptime). Ela é muito divertida e alegra nossos dias.

Mais uma vez, essa citação mostra a importância da interação do apresentador com o público para os Louquitos, estabelecendo um vínculo emocional. Inclusive, a maioria dos entrevistados desse grupo prefere assistir os 
programas ao vivo pelo canal do Shoptime no YouTube, uma vez dito que a plataforma de compartilhamento de vídeos disponibiliza um chat para os telespectadores no qual os Louquitos podem comunicar entre si e com a equipe da TV.

Quando se trata de preferência por alguma marca, todos Louquitos entrevistados são mais propensos a comparem produtos de Casa \& Conforto do que um igual do concorrente. Dentre todos os itens de cama, mesa e banho na casa dos Louquitos, os entrevistados relataram que majoritariamente, se não todos, são itens da marca exclusiva do Shoptime. De acordo com a Teoria do Julgamento Social (PRIMO, 2014), é possível analisar esse comportamento visto que os Louquitos assimilam que todos os produtos de Casa \& Conforto são tão bons quanto aqueles que já compraram sem mesmo ter comparado com a concorrência.

Ao serem questionados sobre o grupo "Loucos por Shoptime", os Louquitos demonstraram felicidade e orgulho por participarem do grupo. Todos os entrevistados confessaram terem feitos amigos dentro do grupo. Inclusive, o Entrevistado $5 \mathrm{~A}$ relatou que o único ponto negativo do grupo na sua opinião é a falta de liberdade das postagens. Ele queria postar outros assuntos que fogem de produtos do Shoptime, como política e fotos pessoais, porém, as administradoras do grupo filtram todas as publicações, deixando apenas o que foi proposto pelas regras. É possível avaliar que esse entrevistado gostaria de compartilhar mais temas para publicações, pois entende que os membros são seus amigos.

Ademais, é entendível a razão pelo qual conseguiram estabelecer relações de amizade com membros do grupo visto que eles compartilham vários valores. Da mesma forma, a Entrevistada 6A descreveu que em todo Aniversário Casa \& Conforto reúne-se com duas vizinhas que também são Louquitas para ficarem comprando produtos da marca juntas.

De acordo com Schiffaman e Kanuk (2000), os produtos que um indivíduo possui, gostaria de ter ou não quer, são associados com o reflexo da autoimagem dele. Como os membros participam desse grupo, é possível reparar uma motivação para se manterem atualizados nas compras e postagens realizadas. Eles compram os itens independentemente de seu benefício funcional, os Louquitos buscam construir uma autoimagem como parte de um grupo que ama o canal Shoptime e suas marcas próprias. O relato da Entrevistada 2A demonstra a necessidade de colecionar produtos apenas para ter e pertencer ao grupo: 
Fico feliz com o grupo, essa semana eles comemoraram minhas compras porque completei todas as cores do banho Basics. Agora vou partir para as roupas de cama da coleção.

Outrossim, os Louquitos têm uma atitude perante o grupo com função expressiva de valor, em outras palavras, têm como objetivo expressar seus valores e a autoimagem (HAWKINS; MOTHERSBAUGH; BEST, 2007). Assim, no grupo, como todos compartilham dos mesmos valores, se sentem despreocupados de julgamentos de terceiros.

Da mesma forma, de acordo com a visão de Solomon (2011), é possível identificar que os Louquitos demonstram o maior nível de envolvimento de atitude. Esse grupo de entrevistados têm suas atitudes internalizadas, isso quer dizer que suas atitudes são tão importantes a eles que se tornaram valores, e assim, dificilmente irão mudar.

\subsubsection{Comparação das Respostas entre os Grupos de Entrevistados}

Ao realizar a comparação dos dois grupos de entrevistados, um aspecto que ressaltou a divergência entre os dois grupos foi a questão do afeto pela marca. Ao serem questionados se os entrevistados gostavam de Casa \& Conforto, todos sem exceção afirmaram que sim. Todavia, é notável o favoritismo explicito dos Louquitos. Uma das vantagens de realizar entrevistas profundas é a interatividade maior entre entrevistado e entrevistador, conseguindo assim extrair mais informações do que as previstas no roteiro planejado (NOTESS; WALKER 2006). Uma das sutilezas percebidas foi o entusiasmo dos Louquitos por Casa \& Conforto. Foi possível observar que os membros desse grupo tiveram entrevistas mais longas, foram mais receptivos e responderam à mensagem os convidando para a pesquisa mais rapidamente. Uma das principais razões pelo qual isso ocorreu é o fato de que o assunto da investigação era de interesse para os Louquitos. Os entrevistados de fato amam Casa \& Conforto e ficam felizes ao dissertar sobre o assunto. Inclusive, a Entrevistada 6A ficou o resto do dia conversando sobre Jogos de Banho Casa \& Conforto com a entrevistadora. É evidente a divergência da intensidade do afeto entre os grupos.

Essa disparidade de adoração de Casa \& Conforto é a razão pelo qual os Louquitos se encaixam como consumidores verdadeiramente leais, diferentemente dos consumidores tradicionais. De acordo com Mowen e Minor (1998), a lealdade verdadeira é composta pelo comportamento de recompra e 
forte atitude positiva. Em outras palavras, um consumidor leal é aquele que, além de comprar frequentemente uma marca, também adora a marca. Ao analisar a frequência de compra entre os grupos, foi conferido que não há diferenças significativas no intervalo de recompra dos consumidores. Todavia, o que diverge dos grupos é justamente a intensidade de seu afeto pela marca. Examinando a Figura 3, a tabela de tipos de lealdade de Dick e Basu (1994), é possível estabelecer que enquanto os Louquitos são considerados consumidores verdadeiramente leais, o grupo de consumidores tradicionais pode ser identificado como falsamente leal. Em outras palavras, esse grupo de entrevistados tem recompra frequente, contudo, não há comprometimento e preferência por Casa \& Conforto perante outras marcas.

Ao investigar sobre os fatores que mais afetam a decisão de compra de cada um dos grupos, é possível notar uma disparidade de prioridade. Enquanto os consumidores tradicionais prezam pela avaliação nos sites posto que é uma maneira de verificação da qualidade do produto, os Louquitos preferem assistir aos programas de TV. Portanto, é possível observar que os consumidores tradicionais são motivados a realizar a compra a partir de necessidades utilitárias da mesma forma que os Louquitos são movidos por necessidade hedônicas. Como explicado por Solomon (2011), a motivação é uma força que estimula o indivíduo a suprir uma necessidade não satisfeita. Essas necessidades podem ser classificadas como utilitária ou hedônicas. Os consumidores tradicionais buscam obter um benefício funcional através das características tangíveis dos produtos de Casa \& Conforto. Esse grupo sempre enfatiza que quer comprar itens de qualidade, ou seja, procura produtos que vão oferecer o benefício funcional que é proposto, desde o jogo de toalhas que secam o corpo rapidamente, aos jogos de cama suaves aos toques, e os cobertores que aquecem seus corpos. Concomitantemente, os Louquitos buscam suprir necessidades hedônicas ao comprar um produto de Casa \& Conforto, visto que procuram obter alegria e pertencimento de um grupo. Como dito anteriormente, o grupo "Loucos por Shoptime" faz com que os Louquitos sintam mais uma carência de obter novos produtos para continuarem atuais dentro do grupo. Desse modo, os Louquitos realizam compras para suprir uma necessidade hedônica.

Essa questão pode ser mais uma vez confirmada pelas respostas da questão que os entrevistados tinham que responder o que mais gostavam na marca Casa \& Conforto. Os consumidores tradicionais tiveram respostas relacionadas a suas características tangíveis, como "suas linhas de banho" ou 
"produtos $100 \%$ algodão", ressaltando mais uma vez que esses procuram suprir uma necessidade utilitária. Ao passo que os Louquitos responderam que mais gostam de Casa \& Conforto por outros aspectos como "compor meu lar" ou "sempre inovando". Inclusive, o Entrevistado 5A informou o seguinte:

Casa \& Conforto traz cultura. Há pouco tempo, eles fizeram uma coleção inspirada em diferentes países. Aprendi muito com os apresentadores explicando cada colcha.

É visível a divergência da atitude e das motivações entre os grupos. Os tradicionais dão ênfase a aspectos tangíveis que podem ser facilmente comparados aos concorrentes, a fim de realizar uma avaliação acerca de sua qualidade. Diferentemente, os Louquitos preferem o aspecto emocional da marca, ao modo que impacta na vida deles.

Uma vez dito que os Louquitos são motivados a comprar a partir de necessidades hedônicas, seguindo o Modelo de Hierarquia de Efeitos (PETER; OLSON, 2009), é possível alinhar que esse grupo de entrevistados segue a hierarquia experiencial. Ou seja, esse grupo tem afeto pela marca Casa \& Conforto, e isso o estimula a comprar um produto e, após a aquisição, forma uma crença a partir desse item comprado (AVERY et al., 2010). Diferentemente, os consumidores tradicionais seguem a hierarquia de aprendizagem padrão no qual primeiramente conhecem um produto a partir de suas características, seja pela TV ou pelo site, e depois desenvolvem algum sentimento perante esse produto e, por fim, avaliam se devem realizar a compra ou não (PETER; OLSON, 2009). 


\section{CONCLUSÕES E RECOMENDAÇÕES PARA NOVOS ESTUDOS}

O presente estudo teve como objetivo analisar e comparar a percepção, a atitude e a motivação de consumidores leais e consumidores tradicionais da marca Casa \& Conforto do Shoptime. Para isso, foram realizadas entrevistas em profundidade com 14 indivíduos, sete consumidores tradicionais e sete consumidores leais, os autodenominados de Louquitos por fazerem parte do grupo "Loucos por Shoptime". A partir da análise de dados, foi possível chegar a algumas conclusões.

Percebeu-se que os Louquitos são mais emocionalmente envolvidos com a marca do que os consumidores tradicionais. Por serem verdadeiramente leais, além da recompra, também têm adoração por Casa \& Conforto. Essa é uma das principais razões da diferença dos comportamentos dos consumidores tradicionais e dos Louquitos.

Em relação à percepção dos consumidores, os tradicionais associam Casa \& Conforto a aspectos tangíveis dos produtos, como qualidade e preço. A questão de encontrar itens com bom custo-benefício é de extrema importância para esse grupo de entrevistados. Como realizam sempre pesquisas de mercado, os consumidores tradicionais estão constantemente comparando os produtos de Casa \& Conforto com os concorrentes. Assim, visto que Casa \& Conforto é uma marca própria do Shoptime, assim como outras marcas exclusivas, historicamente tem margens maiores, possibilitando praticar preços mais baratos que os da concorrência. Da mesma forma, marcas exclusivas podem ter o mesmo fornecedor da concorrência, garantindo sua paridade na qualidade. No caso de Casa \& Conforto, isso ocorre com uma das suas principais concorrentes na percepção desse grupo de entrevistados, a Buddemeyer. O fornecedor é o mesmo, logo, eles têm a mesma qualidade. Todavia, a marca própria do Shoptime consegue sustentar preços menores, resultando em um custo-benefício melhor.

Ao analisar os consumidores leais, os Louquitos, notou-se que sua percepção da marca difere dos consumidores tradicionais. Esse grupo associa a marca com aspectos mais intangíveis, como "exclusividade" e "família". É perceptível que os Louquitos têm mais conhecimento sobre marcas próprias e 
suas vantagens. Como esse grupo é emocionalmente envolvido com a marca, a associam com sentimentos e experiencias de sua vida, aumentando cada vez mais seu comprometimento com ela.

Outrossim, esse vínculo emocional também pode ser evidenciado pela importância dada aos programas ao vivo da TV. A interação com os apresentadores é uma forma de aumentar sua relação com a marca. Diferentemente, o fator mais importante na decisão de compra dos consumidores tradicionais é a avaliação do item no site. Nele, esse grupo de entrevistados podem conferir a qualidade e julgar o custo-benefício do item antes da compra.

Ademais, a ligação emocional entre Louquitos e Casa \& Conforto garante a lealdade desse tipo de consumidor com a marca, assegurando que não irão comprar no concorrente. Em contraste, os consumidores tradicionais frequentemente comparam os preços no mercado, assim, compram o que oferece o melhor custo-benefício. Assim, não são leais à marca Casa \& Conforto.

Da mesma forma que os Louquitos encontram formas de aumentar sua interatividade com a marca e seu vínculo emocional, a participação do grupo é vista como algo extremamente positivo. O elo dos membros "Loucos por Shoptime" é feita pelo compartilhamento de valores, criando uma comunidade onde todos podem ser fanáticos sem julgamento alheio.

Os consumidores tradicionais têm uma assimilação positiva dos Louquitos, achando encantador seu comportamento, melhorando a atitude perante a marca Casa \& Conforto uma vez dito que é uma marca que acolhe seus consumidores ao ponto de serem fanáticos. Da mesma, os consumidores tradicionais podem também alterar sua percepção da marca, a associando com zelo, afeto e carinho. Todavia, a motivação de compra dos consumidores tradicionais não é afetada pelos consumidores leais. Esse grupo de entrevistados acreditam que os Louquitos não têm credibilidade devido ao tamanho de seu afeto com a marca, o fanatismo pode ocasionar uma cegueira e maior tolerância para erros. Assim, suas recomendações não são importantes para os consumidores tradicionais. 


\subsection{Recomendações Gerencias}

A partir da análise dos dados e suas conclusões, surgiram algumas recomendações gerenciais para a marca Casa \& Conforto visando o aumento de vendas, receita e market share do mercado de cama, mesa e banho.

A primeira recomendação é a participação dos responsáveis pela marca no grupo Loucos por Shoptime com a finalidade de observar os elogios e as recomendações dos Louquitos.

Visando aumentar as vendas para os Louquitos e o seu vínculo emocional com a marca, Casa \& Conforto poderia realizar ações específicas para os membros do grupo. Poderiam divulgar um código de desconto nas compras por televendas exclusivos aos Louquitos por e-mail. Também, poderiam desenvolver mais produtos em homenagem ao grupo. Em 2021, a marca fez o lançamento do Jogo De Toalhas Banho Loucos Por Shoptime Branco/roxo 5 Peças - Casa \& Conforto By Buddemeyer no qual rendeu várias postagens positivas no grupo. Mais itens de cama, mesa e banho enaltecendo seus consumidores leais é mais uma maneira de demonstrar prestígio e aumentar o elo emocional com esses. Da mesma forma, ao ofertarem produtos exaltando esse grupo, os Louquitos podem se sentir uma compulsão para adquirir os itens, aumentando as vendas.

Como o fator mais importante na decisão de compra dos Louquitos são os programas da TV, a marca também poderia instruir os apresentadores a frisarem certos termos para estimular associações positivas e expandir o vínculo emocional dos Louquitos, como "família", "lar", "momentos". Outrossim, os apresentadores poderiam ser influenciados a aumentarem a interação com os telespectadores, seja com recados ou ligações ao vivo. Desse modo, os Louquitos iram se sentir mais próximos da marca e possivelmente aumentariam as vendas. Também, os apresentadores poderiam anunciar o grupo nos programas ao vivo. Além de prestigiarem o grupo, fortificando o vínculo emocional dos Louquitos, os apresentadores também iriam informar outros consumidores leais sobre a existência dessa comunidade e os consumidores tradicionais que visam participar, aumentando os seus membros.

Igualmente, Casa \& Conforto poderia lançar produtos e descontos específicos em comemoração de datas que homenageiam outros membros da família, como Dia dos Avós, com a finalidade de aumentar a associação com a "família" a marca e a ligação com o consumidor. Atualmente, a marca já realiza coleções para o dia das mães, dos pais e das crianças. 
Também visando aumentar as compras dos Louquitos, Casa \& Conforto poderia investir em desenvolver estampas que têm mais de uma linha de produto. Por exemplo, a estampa Herbal é uma das mais antigas da marca, ela tem jogo de banho, jogo de cama e enxoval. Aumentando o portfólio com estampas que abrangem mais de uma linha poderia estimular os Louquitos a quererem completar todos os itens. A marca poderia fazer essa estratégia com as estampas mais vendidas de cada linha, visando expandir as vendas.

Da mesma forma, Casa \& Conforto deveria reconhecer os Louquitos como uma comunidade de marca e consultar a opinião desse grupo em certas decisões estratégicas da marca. Por exemplo, os responsáveis comerciais de Casa \& Conforto poderiam questionar os Louquitos sobre novas coleções. Além de aumentar o vínculo emocional com a marca, os Louquitos estão sendo internamente envolvidos nas decisões da sua marca preferida. Do ponto de vista comercial, a marca pode aumentar suas vendas por oferecer produtos mais relevantes ao público-alvo.

Do mesmo modo, a marca também deveria investir em estratégias que visam aumentar as vendas dos consumidores tradicionais. Como o fator de decisão de compra mais importante para esse grupo é a avaliação dos produtos nos sites, a marca poderia estimular seus consumidores a responderem ao e-mail pós-venda solicitando a opinião deles. Casa \& Conforto poderia disponibilizar um desconto exclusivo não cumulativo na sua próxima compra de itens Casa \& Conforto para cada avaliação respondida. Assim, além de ajudar na motivação de compra de outros consumidores, os que responderam iriam se sentir incentivados a utilizarem esse cupom e realizar mais compras na marca.

Da mesma forma, o marketing poderia desenvolver uma forma mais rápida de classificar os itens e deixando mais fácil de deixar sua crítica, visando aumentar as avaliações e, consequentemente, as vendas. Ao invés de obrigarem o cliente a escrever um pequeno texto sobre o item, as avaliações poderiam ser mais objetivas. A marca poderia disponibilizar uma escala de um a cinco em diversas questões como "qualidade" e "preço", e disponibilizar uma média final de todos esses atributos. Assim, os consumidores tradicionais poderiam visualizar as avaliações de modo mais eficaz, dividido por características dos itens.

Por fim, como os consumidores tradicionais prezam muito por qualidade, a marca Casa \& Conforto poderia investir em produtos de qualidade superior aos que oferecem no sortimento atualmente. Por ser uma marca própria, Casa \& Conforto historicamente consegue oferecer preços melhores devido a sua 
margem. Assim, a marca consegue aumentar suas vendas com os consumidores tradicionais uma vez dito que esses procuram e prezam por custobenefício.

\subsection{Sugestões e recomendações para novos estudos}

Para futuros estudos, seria interessante realizar a pesquisa exploratório e qualitativa, por meio de entrevistas em profundidade, com mais consumidores tradicionais e consumidores leais, os Louquitos, com a finalidade de aumentar o número de entrevistados e realizar uma análise mais precisa sobre as percepções, atitudes e motivações dos grupos.

Uma limitação do estudo foi a falta de uma pesquisa quantitativa posterior à quantitativa para proporcionar mais análise sobre o assunto. Sugere-se, então, que seja desenvolvido o Modelo Fishbein para compreender a atitude de consumidores de Casa \& Conforto perante seus concorrentes.

Da mesma forma, visando compreender melhor a influência dos Louquitos, uma pesquisa deveria ser realizada com não-compradores da marca. Assim, Casa \& Conforto poderia entender com mais profundidade se o comportamento dos seus consumidores leais é um benefício ou maleficio para a marca, visando criar estratégias para aumentar sua base de clientes. 


\section{REFERÊNCIAS BIBLIOGRÁFICAS}

AAKER, D. A. (1991), "Managing brand equity", New York: Free Press

Americanas Marketplace (2021). Shoptime: saiba tudo sobre o primeiro home shopping do Brasil. Americanas Marketplace, 2021. Disponível em: https://blog.americanasmarketplace.com.br/2021/06/24/shoptime/. Último acesso: 09/11/2021

AVERY, J; BEATTY, S; HOLBROOK, M; KOZINETS, R; MITTAL, B; RAGHUBIR, P; WOODSIDE, A. Consumer Behavior. Human Pursuit of Happiness in the World of Goods. 2a ed. Kent Drury, Roxanne; Tenaglia, Maria : 2010

BRITES, A. Sistema sensorial - Órgãos captam estímulos e informações. EDUCAÇÃO UOL, novembro 2009. Disponível em: https://educacao.uol.com.br/disciplinas/biologia/sistema-sensorial-orgaoscaptam-estimulos-e-informacoes.htm. Último acesso: 31/08/2021

CARDOSO, T. O que houve com a lealdade dos consumidores?. Isto é Dinheiro, São Paulo, novembro de 2019. Disponível em: https://www.istoedinheiro.com.br/o-que-houve-com-a-lealdade-dosconsumidores/. Último acesso: 14/10/2021

CRESWELL, J. Projeto de Pesquisa: Métodos Qualitativo, Quantitativo e Misto. $3^{\mathrm{a}}$ ed. Porto Alegre: Artmed. 2003

DICK, A.; BASU, K. Customer loyalty: toward an integrated conceptual framework. Journal of the Academy of Marketing Science, vol.22, n.2, p. 99-114, 1994.

ELLIS, T. B. The development, psychometric evaluation and validation of a customer loyalty scale Cardondale, 2000. Doctoral Dissertation (Doctor of Philosophy in Psychology), Department of Psychology in the Graduate School Southern Illinois University 
FERNANDES, M. Fidelização e retenção de clientes: vantagens, benefícios e maneiras para se aplicar. Projep, Minas Gerais, maio 2020. Disponível em: https://projepjr.com/fidelizacao-e-retencao-de-clientes-vantagens-beneficios-emaneiras-para-se-aplicar/. Último acesso: 14/10/2021

FLEFLTO. A internet quer saber: o que Luísa Sonza fala de trás para frente em 'Interesseira'?. BUZZFEED, São Paulo, agosto 2021. Disponível em: https://buzzfeed.com.br/post/a-internet-quer-saber-o-que-luisa-sonza-fala-detras-para-frente-em-interesseira. Último acesso: 13/09/2021

GABRIEL, L. O que é Brand Equity e como utilizá-lo no Marketing Digital. Rock Content, fevereiro $2018 . \quad$ Disponível em: https://rockcontent.com/br/blog/brand-equity/. Último acesso: 29/03/2021

GABRIEL, M. (2020). As Marcas mais Leais aos Consumidores. Futuro dos Negócios, novembro 2021. Disponível no link: https://futurodosnegocios.com.br/blog/as-marcas-mais-leais-aos-consumidores. Último acesso: 28/03/2021

GIL, A.; Métodos e Técnicas de Pesquisa Social. São Paulo: Editora Atlas, 2008.

GIRALDI,J.; IKEDA, A.; CARVALHO, D. Atitudes em relação a produtos brasileiros: uma investigação com estudantes holandeses. RAM, Rev. Adm. Mackenzie 9 (3) • Jun 2008. Disponível em: https://doi.org/10.1590/S167869712008000300002. Último acesso: 15/09/2021

HANHAN, M. (2018) 3 Pilares da Lealdade à Marca e Defesa do Consumidor. Genesys, junho 2018. Disponível em: https://www.genesys.com/pt-br/blog/post/3pilares-da-lealdade-marca-e-defesa-consumidor. Último acesso: 19/03/2021 HAWKINS, Del L.; MOTHERSBAUGH, David L.; BEST, Roger J. Comportamento do consumidor. BELHASSOF, Cláudia Mello (trad). Rio de Janeiro: Campus, 10. ed, 2007.

HELENE, A.; XAVIER, G. A construção da atenção a partir da memória. Braz. J. Psychiatry 25 (suppl 2) • Dez 2003. Disponível em: https://doi.org/10.1590/S1516-44462003000600004. Último acesso: 14/09/2021 
HOYER, W.; MACLNNIS, D. Comportamento do Consumidor.5a ed. Cengage Learning, 2011.

JACOBY,J.; CHESTNUT, R. Brand Loyalty, Measurement and Management. New York: John Wiley \& Sons, 1978

LARÁN, J.; ESPINOZA, F. Consumidores satisfeitos, e então? Analisando a satisfação como antecedente da lealdade. Artigos • Rev. adm. contemp. 8 (2) - Jun 2004. Disponível em: https://doi.org/10.1590/S1415-65552004000200004. Último acesso: 13/10/2021

LIMA, E (2020). Apenas $5 \%$ dos consumidores brasileiros são leais às marcas. Emobile, fevereiro 2020. Disponível em: https://emobile.com.br/site/varejo/apenas-5-dos-consumidores-brasileiros-saoleais-as-marcas/. Último acesso: 19/03/2021

LOPES, J. (2020). O melhor guia para lealdade à marca. Site Classificado, outubro 2020. Disponível em: https://www.fazersiteclassificados.com.br/sites/omelhor-guia-para-lealdade-a-marca/. Último acesso: 20/03/2021

LULIO, M. (2019). 71\% dos consumidores são mais fiéis a marcas que facilitam o engajamento. Consumidor Moderno, agosto 2019. Disponível em: https://www.consumidormoderno.com.br/2019/08/09/71-consumidoresengajamento/. Último acesso: 20/03/2021

MORAIS, F (2011). O desejo das marcas: consumidores leais. Ecommerce Brasil, dezembro 2011. Disponível em: https://www.ecommercebrasil.com.br/artigos/o-desejo-das-marcasconsumidores-leais/. Último acesso: 20/03/2021

MOWEN, J. C.; MINOR, M. Consumer behavior 5. ed. Upper Saddle River: Prentice-Hall, 1998.

NOTESS, C.; WALKER, B. Exploring the Relationships among Liminal Transitions, Symbolic Consumption, and the Extended Self;. Psychology \& Marketing (1986-1998), vol.14, New York: Jan 1996. 
OLIVER, R. L. Whence consumer loyalty? Journal of Marketing, vol.63 (special issue), p. 33-44, 1999.

PAIM, I. Curso de psicolpatologia. São Paulo: EPU, 1993.

PETER, J; OLSON, J. Comportamento do Consumidor e Estratégia de Marketing. 8a ed. McGraw-Hill, 2009

PEZZOTTI, R (2019). Menos leais, consumidores querem que marcas "façam a coisa certa". Economia UOL, São Paulo, outubro 2019. Disponível em: https://economia.uol.com.br/noticias/redacao/2019/10/20/consumidoresquerem-confiar-nas-marcas---mas-sao-menos-leais.htm. Último acesso: $19 / 03 / 2021$

PRIMO, C. Motivação e Atitudes no consumo. Slides Player, Universidade PUC Goais, Goiânia. Disponível em: https://slideplayer.com.br/slide/1229817/. Último acesso: $14 / 09 / 2021$

RIBEIRO, M. P. A lealdade à marca enquanto fator determinante da fidelização de clientes: estudo comparativo aplicado às marcas comercializadoras de combustível. Dissertação Mestrado em Marketing Relacional. Leiria, Setembro de 2015

ROBBINS, S.; JUDGE, T.; SOBRAL, F. Comportamento Organizacional. São Paulo: Pearson Education do Brasil. 2010

SANTOS, V. Lealdade A Marca: Os Fatores Responsáveis Que Leva Uma Empresa A Ser Reconhecida Pela Sua Marca. FACE - Faculdade Casa do Estudante. Aracruz - ES, 2017.

SCHIFFMAN, L.; KANUK,L. Comportamento do consumidor. 6a Ed. Rio de Janeiro: Prentice Hall, 1997

SILVA, J. e ROZESTRATEN, R. Manual Prático de Psicofísica. Instituto de Estudos Brasileiros, Universidade de São Paulo, agosto de 2018. Disponível em: $\quad$ http://www.ieb.usp.br/wp-content/uploads/sites/392/2018/08/manual-depsicofisica.pdf. Último acesso: 12/09/2021 
SOLOMON, M. O Comportamento do Consumidor - Comprando, possuindo e sendo. 9 ed. Porto Alegre: Bookman, 2011

TAVARES, Fred. Gestão de Marca: estratégia e marketing/Fred Tavares-Rio de Janeiro: E-papers Serviços Editoriais Ltda, 2003

ZIKMUND, W. G. Princípios da Pesquisa de Marketing. 2a ed. Cristina Bacellar (trad): Thomson, 2006. 


\section{Apêndice 1}

\section{Roteiro de entrevistas - Louquitos}

Olá, boa tarde! Meu nome é Virginia e essa pesquisa faz parte do meu trabalho de conclusão do curso de Administração de empresas na PUC- Rio. Primeiramente, gostaria de agradecer por dispor seu tempo para me ajudar nessa etapa do projeto. Sua participação é fundamental para minha pesquisa. $O$ objetivo é avaliar o comportamento de compra de consumidores de Casa \& Conforto, marca exclusiva da Shoptime. Gostaria de ressaltar que suas respostas serão unicamente usadas para fins acadêmicos e sua identidade será mantida em anonimato. Então, fique à vontade para falar o que desejar.

1. Antes de mais nada, você poderia me informar sua idade, o bairro onde mora e o seu grau de escolaridade, por favor? (Perfil do entrevistado)

2. Como você conheceu a marca Casa \& Conforto? (Perfil do entrevistado)

3. Você assiste os programas ao vivo do Shoptime na TV ou YouTube? (Perfil do entrevistado)

4. Há quanto tempo você é consumidor de Casa \& Conforto? (Perfil do entrevistado)

5. O que você associa à marca Casa \& Conforto? (Percepção)

6. Descreva a marca Casa \& Conforto em três palavras. (Percepção)

7. Você gosta da marca Casa \& Conforto? (Atitude)

8. O que você mais gosta nela? (Atitude)

9. Com que frequência você compra produtos da marca? (Motivação)

10. O que você mais gosta e o que menos gosta dos programas ao vivo? (Atitude)

11. Quão importante é o programa ao vivo como fator na sua decisão de compra? (Motivação)

12. Quão importante é o preço como fator na sua decisão de compra? (Motivação)

13. Quão importante é a avaliação do produto como fator na sua decisão de compra? (Motivação) 
14. Você leva em consideração outras marcas quando realiza uma compra de cama, mesa e banho? (Motivação)

15. Você é mais propenso a comprar um item Casa \& Conforto sobre um igual de outro concorrente? Por quê? (Motivação)

16. De todos os itens de cama, mesa e banho que você possui, qual é a marca que você mais compra? (Motivação)

17. Você participa do grupo dos Loucos por Shoptime em alguma rede social? (Motivação)

18. Você gosta de participar desse grupo? Quais são as vantagens? (Motivação)

19. E quais são as desvantagens? (Motivação)

20. Você compraria um produto caro e mal ou não avaliado no site, mas que foi bem falado no grupo dos Loucos por Shoptime? (Atitude)

Obrigado por sua participação na pesquisa 


\section{Apêndice 2}

\section{Roteiro de entrevistas - Tradicionais}

Olá, boa tarde! Meu nome é Virginia e essa pesquisa faz parte do meu trabalho de conclusão do curso de Administração de empresas na PUC- Rio. Primeiramente, gostaria de agradecer por dispor seu tempo para me ajudar nessa etapa do projeto. Sua participação é fundamental para minha pesquisa. $O$ objetivo é avaliar o comportamento de compra de consumidores de Casa \& Conforto, marca exclusiva da Shoptime. Gostaria de ressaltar que suas respostas serão unicamente usadas para fins acadêmicos e sua identidade será mantida em anonimato. Então, fique à vontade para falar o que desejar.

1. Antes de mais nada, você poderia me informar sua idade, o bairro onde mora e o seu grau de escolaridade, por favor? (Perfil do entrevistado)

2. Como você conheceu a marca Casa \& Conforto? (Perfil do entrevistado)

3. Você assiste os programas ao vivo do Shoptime na TV ou YouTube? (Perfil do entrevistado)

4. Há quanto tempo você é consumidor de Casa \& Conforto? (Perfil do entrevistado)

5. O que você associa à marca Casa \& Conforto? (Percepção)

6. Descreva a marca Casa \& Conforto em três palavras. (Percepção)

7. Você gosta da marca Casa \& Conforto? (Atitude)

8. O que você mais gosta nela? (Atitude)

9. Com que frequência você compra produtos da marca? (Motivação)

10. O que você mais gosta e o que menos gosta dos programas ao vivo? (Atitude)

11. Quão importante é o programa ao vivo como fator na sua decisão de compra? (Motivação)

12. Quão importante é o preço como fator na sua decisão de compra? (Motivação)

13. Quão importante é a avaliação do produto como fator na sua decisão de compra? (Motivação) 
14. Você leva em consideração outras marcas quando realiza uma compra de cama, mesa e banho? (Motivação)

15. Você é mais propenso a comprar um item Casa \& Conforto sobre um igual de outro concorrente? Por quê? (Motivação)

16. De todos os itens de cama, mesa e banho que você possui, qual é a marca que você mais compra? (Motivação)

17. Você conhece o grupo dos Loucos por Shoptime em alguma rede social? (Motivação)

a. Caso "sim" à resposta 16: o que você acha desse grupo de pessoas? (Atitude)

18. Você acha que ter pessoas que são fãs de Casa \& Conforto uma coisa boa ou ruim? Por quê? (Atitude)

19. Você teria interesse em participar desse grupo? (Motivação)

20. Você compraria um produto caro e mal ou não avaliado no site, mas que foi bem falado no grupo dos Loucos por Shoptime? (Atitude)

Obrigada por sua participação na pesquisa. 